\title{
Hubungan Asupan Zat Gizi dan Indeks Masa Tubuh dengan Hiperlipidemia pada Murid SLTP yang Obesitas di Yogyakarta
}

\author{
Siti Nurul Hidayati ${ }^{1}$, Hamam Hadi' ${ }^{2}$ W.Lestariana ${ }^{2}$
}

\begin{abstract}
Latar belakang. Obesitas pada anak dan remaja meningkatkan risiko penyakit degeneratif dan kardiovaskular. Namun belum jelas apakah remaja yang obesitas berisiko mengalami hiperlipidemia

Tujuan. Menilai hubungan antara indeks masa tubuh (IMT), asupan karbohidrat dan lemak dengan hiperlipidemia pada murid SLTP yang obesitas.

Metoda. Penelitian cross sectional di Yogyakarta. Sampel 109 murid SLTP dengan IMT = persentile-95 kurve IMT dari NCHS-CDC, dipilih secara acak dari murid SLTP yang obesitas, yang didapat pada survei obesitas secara cross sectional. Tinggi badan diukur dengan microtoise dan berat badan diukur dengan timbangan digital. Data asupan karbohidrat dan lemak diperoleh dari wawancara menggunakan FFQ periode 3 bulan terakhir.

Hasil. Prevalensi obesitas murid SLTP 4,9\%, hiperkolesterolemia 88,1\% dan hipertrigliseridemia 100\%. Asupan lemak berhubungan dengan kejadian hiperkolesterolemia $(\mathrm{OR}=6,48$; KI 95\%:2,80-15,02) dan hipertrigliseridemia $(\mathrm{OR}=5,31$; KI 95\%:2,34-12,07). Asupan karbohidrat juga berhubungan dengan kejadian hiperkolesterolemia (OR=5,43; KI 95\%:1,85-15,92) dan hipertrigliseridemia (OR=3,71: KI 95\%:1,34-10,27). IMT tidak berhubungan dengan kejadian hiperlipidemia.

Kesimpulan. Peningkatan asupan lemak dan karbohidrat berhubungan dengan kejadian hiperlipidemia pada anak yang obesitas.
\end{abstract}

Kata kunci: obesitas remaja, asupan zat gizi, indeks masa tubuh, hiperlipidemia.

O besitas mulai menjadi masalah kesehatan di Indonesia, terutama di kota-kota besar. Perkembangan tehnologi dan media elek-

\footnotetext{
Alamat korespondensi:

Dr. Siti Nurul Hidayati

Lab/SMF Ilmu Kesehatan Anak FK UNAIR-RS.Dr.Soetomo, Surabaya

Telpon. 08123527945, email: snurul_h2004@yahoo.com

${ }^{1}$ Lab/SMF Ilmu Kesehatan Anak FK UNAIR-RS.Dr.Soetomo, Surabaya, divisi nutrisi dan penyakit metabolik lab/ smf IKA.

${ }^{2}$ Fakultas Kedokteran Universitas Gajah Mada, Yogyakarta.
}

tronik serta gaya hidup sedentary yang menyebabkan berkurangnya aktifitas fisik yang berakibat menurunnya keluaran energi, serta perilaku kehidupan modern yang merujuk pada pola makan tinggi kalori, tinggi lemak dan kolesterol, semuanya berdampak meningkatkan risiko obesitas. ${ }^{1,2}$

Obesitas pada anak berisiko tinggi menjadi obesitas dewasa dan berpotensi mengalami penyakit metabolik dan penyakit degeneratif di kemudian hari, salah satu diantaranya adalah penyakit kardiovaskular. ${ }^{2,3,4}$ Oleh karena itu faktor risiko penyakit kardiovaskular, antara lain dislipidemia pada anak obesitas harus dievaluasi 
sejak dini, ${ }^{4}$ kadar lipid darah pada anak obesitas menyerupai profil lipid pada penyakit kardiovaskular. ${ }^{3}$ Selain itu, ukuran antropometri dan derajat obesitas juga berkaitan dengan kadar lipid darah, kadar insulin dan tekanan darah. ${ }^{5}$

Penelitian ini dilakukan untuk mengetahui hubungan antara asupan karbohidrat, lemak dan indeks massa tubuh pada murid SLTP yang obesitas dengan kejadian hiperlipidemia.

\section{Metoda}

Penelitian observasional dengan rancangan cross sectional telah dilakukan di SLTP Yogyakarta yang dipilih secara simple random sampling, untuk mengetahui hubungan antara asupan karbohidrat, lemak dan IMT dengan kejadian hiperlipidemia pada murid SLTP yang obesitas.

Subyek penelitian adalah murid SLTP yang obesitas dengan IMT $\geq$ persentil ke 95 kurve IMT menurut umur dan jenis kelamin dari NCHS-CDC. Subyek penelitian dipilih dengan cara simple random sampling dari 460 murid dengan obesitas yang ditemukan pada survei obesitas, berumur 11-15 tahun dan bersedia mengikuti penelitian dengan menandatangani informed consent. Tidak disertakan dalam penelitian bila menderita penyakit sebagai akibat obesitas, seperti diabetes mellitus, penyakit jantung dan hipertensi. Penelitian dilaksanakan di 6 SLTP di Kota Yogyakarta dan 10 SLTP di Kabupaten Bantul, dalam periode bulan September 2003 - Desember 2003.

Instrumen yang digunakan dalam pengumpulan data adalah kuesioner penelitian, food frequency questionnaire (FFQ) untuk 3 bulan terakhir dan food model, timbangan digital berkapasitas $120 \mathrm{~kg}$ dengan tingkat ketelitian 0,1 $\mathrm{kg}$, Microtoise dengan kapasitas panjang $200 \mathrm{~cm}$, tingkat ketelitian $0,1 \mathrm{~cm}$, grafik kurve IMT menurut umur dan jenis kelamin dari NCHS-CDC, diambil sampel darah 3 cc untuk pemeriksaan kadar colesterol dan trigliserida. Pemeriksaan kolesterol total dilakukan dengan menggunakan metode cholesterol oxidase - phenol amino phenazone (CHOD-PAP), trigliserida dengan metode glycerol phosphatase-phenol amino phenazone (GPO-PAP) dan menggunakan kit merek DiaSys.

Data konsumsi zat gizi diolah dengan program Nutrisurvey. Analisis data dilakukan dengan menggunakan program Stata 6, dengan uji statistik uji-t, korelasi dan regresi.

\section{Hasil}

Subyek berjumlah 109 orang dan memenuhi kriteria inklusi, di kota Yogyakarta 60 orang dan di kabupaten Bantul 49 orang. Umur rerata subyek 13,4 tahun dengan rentang nilai 11,3-15,8 tahun. Frekuensi umur terbanyak didapatkan pada kelompok umur $13-15$ tahun. Tingkat sosial ekonomi sampel cukup baik, dilihat dari tingkat pendidikan orang tua yang sebagian besar berpendidikan perguruan tinggi (bapak 52,3\%, ibu 46,8\%) dan berpenghasilan di atas median/ Rp.2.000.000 (58,7\%), serta mempunyai pekerjaan yang relatif mapan (bapak pegawai $64,8 \%$, ibu pegawai 61,5\%). Empat belas persen subyek mempunyai bapak obesitas dan 13,8\% ibu obesitas, riwayat hiperkolesterolemia bapak 12,3\%, ibu 15,4\% ( $\mathrm{n}=65)$.

Rerata asupan lemak 75,2 $\pm 20,03$ gram/hari dengan rentang nilai 24,2 - 143,7 gram/hari, sedang rerata asupan lemak jenuh $55 \pm 16,25$ gram/hari dengan rentang nilai 17,6 - 107,1 gram/hari. Rerata asupan karbohidrat 323,5 $\pm 69,03$ gram/hari dengan rentang nilai 137,1 - 489 gram/hari. Rerata kadar kolesterol $188,6 \pm 5,8 \mathrm{mg} / \mathrm{dl}$ dengan rentang nilai 177,6 - 198,5 $\mathrm{mg} / \mathrm{dl}$, sedangkan rerata kadar trigliserida $169,9 \pm 5,4$ $\mathrm{mg} / \mathrm{dl}$ dengan rentang nilai $159,3-180 \mathrm{mg} / \mathrm{dl}$.

\section{Prevalensi obesitas dan hiperlipidemia}

Diantara 9349 orang murid yang dilakukan skreening, ditemukan 4,9\% (460 orang) obesitas. Prevalensi obesitas pada laki-laki 6,6\%, lebih banyak dibanding perempuan 3,5\%. Prevalensi hiperkolesterolemia $($ kadar kolesterol total $=180 \mathrm{mg} / \mathrm{dl})$ pada penelitian ini $88,1 \%$, laki-laki $63,5 \%$ dan perempuan $36,5 \%$ sedang hipertrigliseridemia (kadar trigliserida $=150$ $\mathrm{mg} / \mathrm{dl}$ ) ditemukan pada semua subyek penelitian, lakilaki $61,5 \%$ dan perempuan $38,5 \%$ (Gambar 1)

Pada Tabel 1 tampak bahwa IMT mempunyai hubungan yang sangat lemah dan tidak bermakna, ini berarti bahwa nilai IMT pada penelitian ini tidak bisa digunakan untuk memprediksikan kadar kolesterol total dan kadar trigliserida. Keeratan hubungan asupan karbohidrat lemah, sedang asupan lemak bersifat sedang terhadap kadar kolesterol total dan trigliserida.

Tabel 2 menunjukkan bahwa asupan lemak jenuh paling banyak menyebabkan perubahan kadar kolesterol total, karena setiap peningkatan 1 gram/hari asupan lemak jenuh akan meningkatkan kadar 
Sari Pediatri, Vol. 8, No. 1, Juni 2006

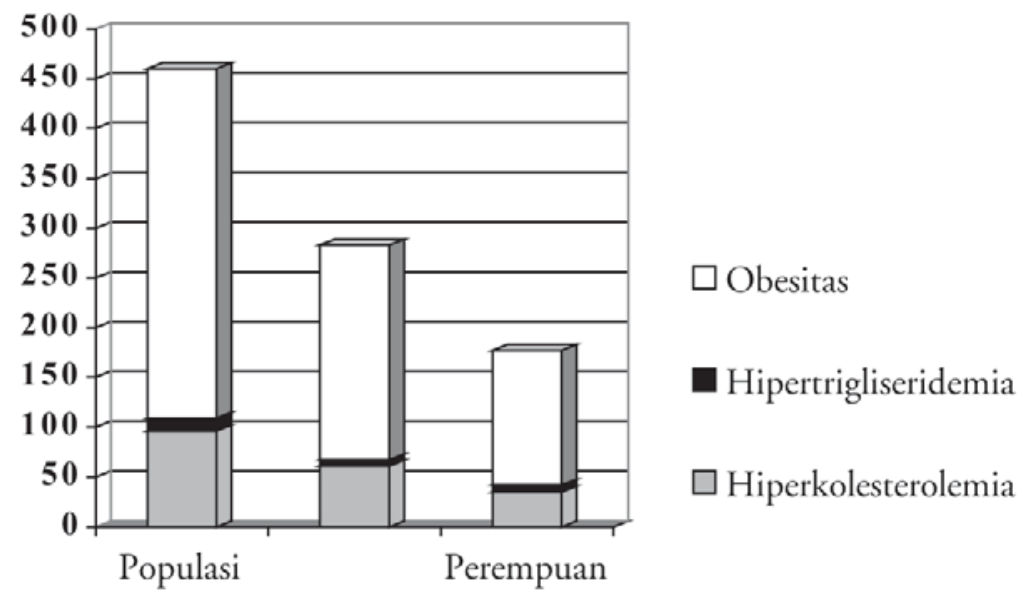

Gambar 1. Prevalensi obesitas dan hiperlipidemia

Tabel 1. Hubungan antara asupan zat gizi dan indeks masa tubuh (IMT) dengan kadar kolesterol total dan kadar trigliserida.

\begin{tabular}{lcccc}
\hline \multirow{2}{*}{ Variabel prediktif } & \multicolumn{2}{c}{ Kadar kolesterol } & \multicolumn{2}{c}{ Kadar trigliserida } \\
\cline { 2 - 5 } & $\mathrm{r}^{*}$ & $\mathrm{P}$ & $\mathrm{r}^{*}$ & $\mathrm{p}$ \\
\hline Indeks masa tubuh & 0,05 & 0,62 & 0,02 & 0,88 \\
Asupan karbohidrat & 0,23 & 0,02 & 0,24 & 0,01 \\
Asupan lemak & 0,47 & $<0,001$ & 0,41 & $<0,001$ \\
Asupan lemak jenuh & 0,44 & $<0,001$ & 0,39 & $<0,001$ \\
\hline
\end{tabular}

$*_{\mathrm{r}}$ : koefisien korelasi

Tabel 2. Pengaruh asupan karbohidrat, lemak dan IMT terhadap kadar kolesterol total

\begin{tabular}{|c|c|c|c|c|c|c|}
\hline \multirow{2}{*}{ Variabel prediktif } & \multicolumn{3}{|c|}{ Regresi linier sederhana } & \multicolumn{3}{|c|}{ Regresi linier ganda } \\
\hline & $\begin{array}{c}\beta \\
\text { (IK 95\%) }\end{array}$ & $\mathrm{p}$ & $\mathrm{R}^{2}$ & $\begin{array}{c}\beta \\
(\text { IK } 95 \%)\end{array}$ & $\mathrm{p}$ & $\mathrm{R}^{2}$ \\
\hline Indeks massa tubuh & $\begin{array}{c}0,094 \\
(-0,28-0,47)\end{array}$ & 0,62 & 0,002 & $\begin{array}{c}-0,08 \\
(-0,42-0,26)\end{array}$ & 0,64 & 0,22 \\
\hline Asupan karbohidrat & $\begin{array}{c}0,006 \\
(0,001-0,01)\end{array}$ & 0,02 & 0,05 & $\begin{array}{c}0,004 \\
(0,001-0,01)\end{array}$ & 0,11 & \\
\hline Asupan lemak & $\begin{array}{c}0,135 \\
(0,09-0,18)\end{array}$ & $<0,001$ & 0,22 & $\begin{array}{c}0,128 \\
(0,08-0,18)\end{array}$ & $<0,001$ & \\
\hline Asupan lemak jenuh & $\begin{array}{c}0,156 \\
(0,09-0,22)\end{array}$ & $<0,001$ & 0,19 & & & \\
\hline
\end{tabular}

IK: interval kepercayaan $\quad \beta$ : koefisien regresi

kolesterol total sebesar $0,156 \mathrm{mg} / \mathrm{dl}$. Namun asupan lemak mempunyai kontribusi terbesar (22\%) terhadap perubahan kadar kolesterol total.

Setelah memperhitungkan variabel prediktif yang lain, ternyata hanya asupan lemak yang dapat memprediksikan peningkatan kadar kolesterol total $(\mathrm{p}<0,001)$, tetapi peningkatan ini lebih rendah $(0,128$ $\mathrm{mg} / \mathrm{dl}$ setiap peningkatan $1 \mathrm{gram} / \mathrm{hari}$ asupan lemak), dan kecenderungan peningkatan kadar kolesterol total juga menjadi lebih rendah (OR 5,67) untuk yang 
Tabel 3. Pengaruh asupan tinggi karbohidrat dan tinggi lemak serta IMT di atas median terhadap kadar kolesterol total

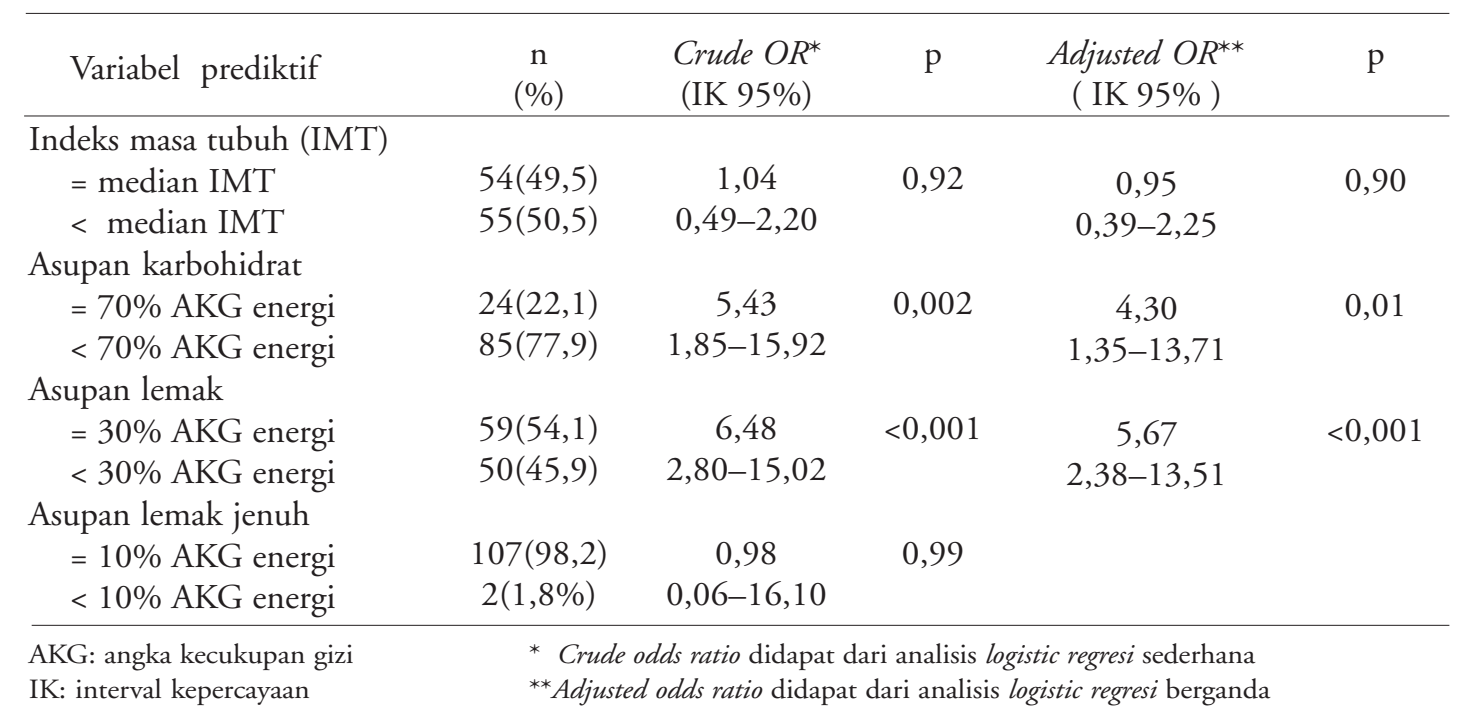

Tabel 4. Pengaruh asupan karbohidrat, lemak dan IMT terhadap kadar trigliserida

\begin{tabular}{lcccccc}
\hline & \multicolumn{3}{c}{ Regresi linier sederhana } & \multicolumn{2}{c}{ Regresi linier ganda } \\
\cline { 2 - 7 } Variabel prediktif & $\begin{array}{l}\beta \\
(\text { IK } 95 \%)\end{array}$ & $\mathrm{p}$ & $\mathrm{R}^{2}$ & $\begin{array}{c}\beta \\
(\text { IK } 95 \%)\end{array}$ & $\mathrm{p}$ & $\mathrm{R}^{2}$ \\
\hline Indeks massa tubuh & $\begin{array}{c}0,027 \\
(-0,32-0,38) \\
0,006\end{array}$ & 0,88 & 0,0002 & $\begin{array}{c}-0,122 \\
(-0,44-0,20) \\
0,004\end{array}$ & 0,45 & 0,17 \\
Asupan karbohidrat & 0,01 & 0,06 & $\begin{array}{c}(-0,00-0,01) \\
0,103\end{array}$ & $<0,001$ \\
Asupan lemak & $\begin{array}{c}0,001-0,01) \\
0,109\end{array}$ & $<0,001$ & 0,17 & $(0,06-0,15)$ & & \\
Asupan lemak jenuh & $\begin{array}{c}(0,06-0,16) \\
0,128\end{array}$ & $<0,001$ & 0,15 & & & \\
\hline
\end{tabular}

IK: interval kepercayaan

${ }^{*} \beta$ : koefisien regresi

asupan lemaknya tinggi. Kondisi ini menunjukkan bahwa asupan karbohidrat dan IMT mempunyai interaksi dengan asupan lemak dalam mempengaruhi kadar kolesterol total dan memberi kontribusi terhadap perubahan kadar kolesterol total sebesar 22\%.

Pada Tabel 3 terlihat asupan karbohidrat yang tinggi (di atas 70\% AKG energi), cenderung 5,43 kali lebih besar menyebabkan peningkatan kadar kolesterol total dibanding yang asupan karbohidratnya normal, sedang asupan lemak tinggi mempunyai kecenderungan 6,48 kali lebih besar menyebabkan peningkatan kadar kolesterol total dibanding yang asupan lemaknya normal. Untuk asupan lemak jenuh, peningkatan 1 gram akan meningkatkan kadar kolesterol total 0,156 $\mathrm{mg} / \mathrm{dl}$. Pada Tabel 4 terlihat bahwa asupan lemak jenuh paling besar menyebabkan perubahan kadar trigliserida, yaitu setiap peningkatan 1 gram/hari asupan lemak jenuh akan meningkatkan kadar trigliserida sebesar $0,128 \mathrm{mg} / \mathrm{dl}$. Namun asupan lemak yang mempunyai kontribusi terbesar terhadap perubahan kadar trigliserida (17\%).

Dengan memperhitungkan variabel prediktif yang lain, ternyata hanya asupan lemak yang dapat memprediksikan peningkatan kadar trigliserida 
$(\mathrm{p}<0,001)$, yaitu untuk setiap peningkatan 1 gram/hari asupan lemak akan meningkatkan kadar trigliserida sebesar $0,103 \mathrm{mg} / \mathrm{dl}$. Kondisi ini menunjukkan bahwa asupan karbohidrat dan IMT mempunyai interaksi dengan asupan lemak dalam mempengaruhi kadar trigliserida dan memberikan kontribusi terhadap perubahan kadar trigliserida sebesar 17\%. Terhadap kadar trigliserida, peningkatan asupan lemak diatas 30\% AKG energi cenderung meningkatkan kadar trigliserida sebesar 5,31 kali lebih besar dibandingkan yang asupan lemaknya normal. Untuk asupan lemak jenuh, setiap peningkatan asupan 1 gram akan meningkatkan kadar trigliserida $0,128 \mathrm{mg} / \mathrm{dl}$ (Tabel 5).

Asupan karbohidrat yang tinggi (diatas 70\% AKG energi), cenderung menyebabkan peningkatan kadar trigliserida sebesar 3,71 kali lebih besar dibanding yang asupan karbohidratnya normal (Tabel 5).

\section{Diskusi}

Prevalensi obesitas pada penelitian ini lebih rendah bila dibandingkan dengan penelitian tahun 1999 pada murid Sekolah Dasar oleh Ismail D, dkk di Yogyakarta $(9,5 \%){ }^{6} \mathrm{Hal}$ ini mungkin disebabkan karena remaja pada penelitian ini telah memahami body image, sehingga mereka memperhatikan penampilan fisik. Menurut Baur, terdapat hubungan yang negatif antara berat badan dengan self-esteem pada remaja tetapi tidak dengan usia anak. ${ }^{7}$ Di Singapura, prevalensi obesitas pada umur 12-13 tahun sebesar $14,7 \%$ dan $13,1 \%$ pada umur 15-16 tahun $^{8}$; perbedaan dengan penelitian ini bisa disebabkan kebiasaan dan pola makan serta tingkat sosial ekonomi.

Prevalensi hiperkolesterolemia pada penelitian ini lebih tinggi dibanding penelitian Rubiana dkk. 1997 pada anak Sekolah Dasar di Denpasar, mendapatkan hiperkolesterolemia $88 \%$ dan 58,8\% hipertrigliseridemia. ${ }^{9}$ Perbedaan disebabkan karena remaja sangat dipengaruhi faktor hormonal yang menurut Jellinger kadar lipid darah berfluktuasi pada masa anak dan remaja. ${ }^{10}$

Hiperlipidemia pada penelitian ini lebih banyak pada laki-laki dibanding perempuan, disebabkan onset pubertas pada laki-laki berbeda dengan perempuan. Menurut Tershakovec, dkk., onset pubertas pada lakilaki terjadi pada usia 9-15 tahun sedang pada perempuan terjadi lebih awal, sehingga pada usia 915 tahun laki-laki mempunyai perubahan profil lipid yang menyolok. ${ }^{5}$ Bogalusa heart study, mendapatkan perbedaan profil lipid remaja laki-laki dengan perempuan karena pengaruh hormon estradiol pada remaja perempuan dan hormon testosteron pada remaja laki-laki, ${ }^{11}$ namun penelitian Jellinger mendapatkan perempuan cenderung mempunyai kadar kolesterol lebih tinggi dibanding laki-laki. ${ }^{10}$

Tabel 5. Pengaruh asupan tinggi karbohidrat dan tinggi lemak serta IMT diatas median terhadap kadar trigliserida

\begin{tabular}{|c|c|c|c|c|c|}
\hline Variabel prediktif & $\begin{array}{c}\mathrm{n} \\
(\%)\end{array}$ & $\begin{array}{l}\text { Crude OR* } \\
\text { ( IK 95\%) }\end{array}$ & $\mathrm{p}$ & $\begin{array}{l}\text { Adjusted } O R^{* *} \\
\quad(\text { IK } 95 \%)\end{array}$ & $\mathrm{p}$ \\
\hline \multicolumn{6}{|l|}{ Indeks massa tubuh } \\
\hline$=$ median IMT & $54(49,5)$ & 1,20 & 0,63 & 1,17 & 0,71 \\
\hline$<$ median IMT & $55(50,5)$ & $0,57-2,55$ & & $0,51-2,71$ & \\
\hline \multicolumn{6}{|l|}{ Asp.karbohidrat } \\
\hline$=70 \%$ AKG energi & $24(22,1)$ & 3,71 & 0,01 & 2,74 & 0,07 \\
\hline$<70 \%$ AKG energi & $85(77,9)$ & $1,34-10,27$ & & $0,92-8,12$ & \\
\hline \multicolumn{6}{|l|}{ Asp.lemak } \\
\hline$=30 \% \mathrm{AKG}$ energi & $59(54,1)$ & 5,31 & $<0,001$ & 4,72 & $<0,001$ \\
\hline$<30 \%$ AKG energi & $50(45,9)$ & $2,34-12,07$ & & $2,04-10,92$ & \\
\hline \multicolumn{6}{|l|}{ Asp.lemak jenuh } \\
\hline$=10 \%$ AKG energi & $107(98,2)$ & 1,05 & 0,97 & & \\
\hline$<10 \%$ AKG energi & $2(1,8)$ & $0,06-17,35$ & & & \\
\hline
\end{tabular}

AKG: angka kecukupan gizi $\quad *$ Crude odds ratio didapat dari analisis logistic regresi sederhana

IK: interval kepercayaan $\quad{ }^{* *}$ Adjusted odds ratio didapat dari analisis logistic regresi berganda 
Pada penelitian ini tidak didapatkan hubungan antara IMT dengan kadar kolesterol dan trigliserida, tetapi lebih berkaitan dengan tipe obesitas. Dengan demikian dapat dikatakan bahwa tidak semua remaja obesitas yang mempunyai indeks masa tubuh tinggi akan mengalami hiperlipidemia, seperti penelitian Brown dkk. yang menemukan peningkatan prevalensi hiperkolesterolemia pada IMT $=25$, tetapi pada IMT $<25$ peningkatan kadar kolesterol tidak konsisten. ${ }^{12}$ Chang dkk. pada penelitiannya terhadap remaja Korea yang obesitas, mendapatkan adanya hubungan positif antara kadar kolesterol dan kadar trigliserida dengan IMT, lemak tubuh dan rasio lingkar pingganglingkar dada. ${ }^{13}$ Sedangkan Pietrobelli dkk menemukan IMT berkaitan dengan berbagai perubahan biokimiawi dan fisiologi yang terjadi akibat obesitas. ${ }^{14}$

Hasil penelitian ini menunjukkan bahwa peningkatan asupan karbohidrat akan meningkatkan kadar kolesterol total (Tabel 2 dan 3), keadaan ini disebabkan karena hasil pemecahan karbohidrat, yaitu glukosa mengalami glikolisis menjadi piruvat yang selanjutnya mengalami dekarboksilasi fosforilasi menjadi asetilKoA untuk menghasilkan energi. Bila asupan karbohidrat berlebihan, maka pembentukan asetilKoA meningkat yang dapat menyebabkan peningkatan pembentukan kolesterol melalui lintasan yang kompleks. ${ }^{15,16}$ Brown dkk menyatakan bahwa setiap $10 \%$ peningkatan asupan karbohidrat akan menurunkan 2,9 mg/dl kadar kolesterol-HDL, dan peningkatan kadar kolesterol total berkaitan dengan tingginya asupan protein, lemak jenuh, dan kolesterol. $^{12}$

Peningkatan asupan lemak juga akan meningkatkan kadar kolesterol total (Tabel 2 dan 3), hal ini disebabkan karena lemak makanan yang sebagian besar dalam bentuk trigliserida mengalami hidrolisis menjadi digliserida, monogliserida dan asam lemak bebas. Asam lemak bebas ini selanjutnya mengalami â-oksidasi menjadi asetil-KoA untuk menghasilkan energi. Bila asupan lemak berlebihan, maka pembentukan asetil-KoA juga meningkat, yang selanjutnya melalui lintasan yang kompleks menjadi kolesterol. ${ }^{15}$ Hal tersebut sesuai dengan yang dikemukakan oleh Waspadji S. ${ }^{17}$ bahwa lemak makanan merupakan komponen makanan yang berpengaruh paling besar terhadap pengaturan metabolisme kolesterol, sehingga asupan lemak yang berlebihan dapat meningkatkan kadar kolesterol total. Pada penelitian Waspadji S. tersebut di- temukan bahwa orang yang mempunyai asupan lemak tergolong tinggi, memiliki risiko menderita hiperlipidemia 2,85 kali lebih tinggi dibandingkan dengan yang mempunyai asupan lemak normal. ${ }^{17}$ Peningkatan asupan lemak jenuh juga meningkatkan kadar kolesterol total (Tabel 2 dan 3). Kondisi ini sesuai dengan hasil penelitian pada tahun 1970-an yang menunjukkan bahwa asupan lemak jenuh berhubungan dengan peningkatan kadar kolesterol total ${ }^{18}$ dan setiap perubahan $1 \%$ asupan energi dari asam lemak jenuh akan meningkatkan $1,74 \mathrm{mg} / \mathrm{dl}$ kadar kolesterol total. ${ }^{12}$ Lemak jenuh merupakan penyebab utama peningkatan kolesterol dan kolesterol-LDL, karena peningkatan lemak jenuh akan menurunkan aktivitas ambilan LDL oleh reseptor LDL dan menurunkan ekskresi kolesterol dalam pembuluh darah, selain itu lemak jenuh meningkatkan produksi LDL. ${ }^{17}$

Peningkatan asupan karbohidrat akan meningkatkan kadar trigliserida (Tabel 4 dan 5) karena bila asupan karbohidrat meningkat pembentukan piruvat dan asetil-KoA juga meningkat sehingga menyebabkan peningkatan pembentukan asam lemak secara de novo dari asetil-KoA. ${ }^{16}$ Asam-asam lemak ini akan mengalami esterifikasi dengan triosefosfat yang dihasilkan dari glikolisis menjadi trigliserida, sehingga terjadi peningkatan kadar trigliserida. ${ }^{15,16}$ Hal tersebut sesuai dengan pendapat Waspadji $S$ bahwa di negara yang sedang berkembang, pada umumnya karbohidrat merupakan sumber energi utama. Di lain pihak, karbohidrat merupakan bahan dasar pembentukan trigliserida sehingga kelebihan asupan karbohidrat akan disimpan dalam bentuk lemak di bawah kulit. Bila asupan karbohidrat yang berlebihan ini berlangsung lama, akibatnya terjadi obesitas yang berkaitan erat dengan peningkatan kadar trigliserida. ${ }^{17} \mathrm{Hal}$ ini sesuai dengan kondisi di Indonesia yang mempunyai sumber energi utama karbohidrat, sehingga dapat menjelaskan mengapa semua subjek mempunyai kadar trigliserida yang tinggi. Temuan ini diperkuat oleh pendapat Jellinger yang menyatakan bahwa peningkatan asupan karbohidrat akan meningkatkan kadar trigliserida. ${ }^{10}$

Peningkatan asupan lemak akan meningkatkan kadar trigliserida (Tabel 4 dan 5) sedangkan untuk lemak jenuh peningkatan asupan akan meningkatkan kadar trigliserida juga. Hal ini karena hampir seluruh lemak yang terdapat dalam makanan $( \pm$ 90\%) terdapat dalam bentuk trigliserida. Trigliserida 
ini mengalami hidrolisis menjadi digliserida, monogliserida dan asam lemak bebas, selanjutnya asam lemak bebas ini akan mengalami esterifikasi dengan triosefosfat untuk membentuk trigliserida ${ }^{15}$; dengan demikian dapat dikatakan bahwa peningkatan asupan lemak akan menyebabkan peningkatan kadar trigliserida.

\section{Kesimpulan}

Pada penelitian ini ditemukan bahwa, asupan lemak dan karbohidrat berhubungan dengan terjadinya hiperlipidemia pada anak yang obesitas, namun IMT tidak berhubungan dengan terjadinya hiperlipidemia.

\section{Daftar Pustaka}

1. Satoto, Karjati S, Darmojo B, Tjokroprawiro A, Kodyat BA. Kegemukan, obesitas dan penyakit degeneratif: epidemiologi dan strategi penanggulangannya. Dalam: Widyakarya Nasional Pangan dan Gizi VI. Jakarta: LIPI; 1998. h. 787-808.

2. Heird WC. Parental feeding behavior and children's fat mass. Am J Clin Nutr 2002; 75:451-2.

3. Taitz LS. Obesity. Dalam: McLaren DS, Burman D, Belton NR, Williams AF. Textbook of Pediatric Nutrition. Edisi ketiga. London: Churchill Livingstone; 1991. h. 485-509.

4. Syarif DR. Childhood obesity: Evaluation and management. Dalam: Adi S, dkk. Naskah Lengkap National Obesity Symposium II. Surabaya; 2003. h. 123-39.

5. Tershakovec AM, Jawad AF, Stallings VA, Cortner JA, Zemel BS, Shannon BM. Age-related changes in cardiovascular disease risk factors of hypercholesterolemic children. J Pediatr 1998; 132:414-20.

6. Ismail D, Herini ES, Hagung P, Sadjimin T. Fast food consumption and obesity: relationship among elemen- tary school students in yogyakarta. Paediatr Indones 1999; 5-6:127-33.

7. Baur LA. Child and adolescent obesity in the $21^{\text {st }}$ century: an Australian perspective. Asia Pacific J Clin Nutr 2002; 1 (Suppl): S524-8

8. Loke KY. Consequences of childhood and adolescent obesity. Asia Pacific J Clin Nutr 2002; 11: S702-4.

9. Rubiana S, Prayoga AA, Sunarka N, Suandi KG, Soetjiningsih. Gambaran klinis dan profil lipid serum pada anak obesitas di sekolah dasar Cipta Darma. Denpasar, Bali. Maj.Kedokt.Indon. 1997; 47: 13 - 8.

10. Jellinger PS. AACE Lipid guidelines. Endocr Pract. 2000; 6:1-52.

11. Bogalusa Heart Study. Lipids and lipoproteins. Diunduh pada 27 Agustus 2003. Didapat dari: http://www.som. tulane.edul cardiohealth/lipids.htm.

12. Brown CD, Higgins M, Donato K.A, Rohde FC, Garrison R, Obarzanek E, Ernst ND, Horan M. Body mass index and the prevalence of hypertension and dyslipidemia. Obesity research; 2000; 6:605-69.

13. Chang KJ, Lee MY, Kim SK. Anthropometric and blood biochemical characteristics, dietary behaviour and health- related lifestyle of Korean obese adolescents. Poster theme 4: Obesity management. Abstract from: Abstract Book: $3^{\text {rd }}$ Asian Congress of Dietetics 2002, Malaysia, P4-4.

14. Pietrobelli A, Faith MS, Allison DB, Gallagher D, Chiumello G, Heymsfield, SB. Body mass index as a measure of adiposity among children and adolescents: a validation study. J Pediatr 1998; 132:204-10.

15. Djojosoebagio S, Piliang WG. Nutrisi lemak. Dalam: Fisiologi nutrisi. Edisi ke 2. Jakarta: Penerbit Universitas Indonesia (UI-Press). 1998. h. 202-50.

16. Murray RK, Granner DK, Mayes PA, Rodwell VW. Harper's biochemistry Edisi Ke-24, Hartono, A, (alih bahasa), Jakarta: EGC, 1997.

17. Waspadji S Penyunting. Pengkajian status gizi, studi epidemiologi. Jakarta: Balai Penerbit FKUI, 2003.

18. HNR:Nutrition $\&$ health, dietary fatty acids and health. Diunduh pada 11 Pebruari 2004. Didapat dari: http:// www.mrc-hnr.cam.ac.uk/NutHlth/fatty_acid.html 